\title{
The Nature of Public University Autonomy in Determining Its Size, Rate of Growth and Expansion: A Case of Kyambogo University
}

\author{
George William Kajura Lubega ${ }^{1}$, Hamza Ahmed Segawa ${ }^{1}$, Win Hope Tukamuheebwa ${ }^{1}$ \& Joseph Kimoga ${ }^{1}$ \\ ${ }^{1}$ College of Education and External Studies, Makerere University, Kampala, Uganda \\ Correspondence: George William Kajura Lubega, College of Education and External Studies, Makere re University, \\ Kampala, Uganda.
}

Received: May 25, 2016

Accepted: June 8, 2016

Online Published: March 22, 2017

doi:10.5430/irhe.v2n 1p110

URL: https://doi.org/10.5430/irhe.v2n1p110

\begin{abstract}
University autonomy is very crucial in the determination of an institution's size, its rate of growth and expansion. This study was conducted at Kyambogo University. The purpose of the study was to establish the nature of institutional autonomy in determining the size, rate of growth and expansion of Kyambogo University. The paper analysed the nature of institutional autonomy with regard to students' enrolment, staffing levels, infrastructure, facilities, financial resources, policy framework, university's partnerships and response to global trends. The study concluded that institutional autonomy is challenged by government established bodies and entities because government plays a central role in regulating the institutional autonomy of higher education institutions in terms of size, growth and expansion. The study recommended that the university should be mindful of this challenge when considering size, rate of gro wth and expansion, that government mainly plays a supervisory role to the university and the university in bid to enjoy a high degree of autonomy, management should move away from the traditional methods of generating income and become entrepreneurial in nature.
\end{abstract}

Keywords: size, growth, expansion, institutional autonomy

\section{Introduction}

Universities are degree awarding institutions providing higher education. The major role of the university is to create and impart knowledge through academic and research development, publish, do community engagement (National Council for Higher Education, 2013). Kyambogo University poses as the leading provider of academic programmes in Uganda (Kyambogo University Strategic Plan, 2013). The university has developed a number of new programmes at both undergraduate and postgraduate levels. With the assumption of $2 \%$ growth in student population for the period between $2012 / 2013$ to $2017 / 2018$, and $10 \%$ for the period 2018/19 to 2022/2023, the student populat ion at the campus and affiliated institutions is estimated at 35,350 and 40,200 respectively.

Universities in Uganda are in two categories; public universities that is, those supported by the state which are eight in number, and the private universities which are owned either by individuals, foundations or group of individuals which total to 32. There are several factors that determine the size, growth and expansion of universities which include: students' enrolment, staffing levels, academic programmes, in frastructural facilities, financial resources, policy frameworks, university's partnerships and global trends. To determine is to influence or make something happen which lead directly to a decision.

According to various authors (Taiwo, 2012; Keiko 2008; O’Neil, 2013; Varghese \& Martin, 2013; Huff, 1984 and Olsen, 2009;- Organization for Economic Co-operation and Development (OECD), 2003), institutional autonomy implies the freedom of universities to select their students and staff by criteria chosen by the universities themselves, autonomy to shape their curricu lu m and syllabus, and freedom to decide how to allocate their various resources such as funds made available to them, degree of self-governance necessary for effective decision-making of institution of high education in relation to their acade mic work, standards, management and other related activities, self-regulation and administrative independence with respect to student's admissions, curriculum, methods of teaching and assessment, research, establishment of academic regulations and internal management of resources generated from both public and private sources. 


\section{Literature Review}

According to Claudius (2015), determination of size, growth and expansion of a university is reflected in alterat ions within university system, global differentiation of the overall system of higher education, changes in the university systems and their political frameworks. The dimensions of size and expansion of a higher education institution are reflected by the differences in students' enrolment, teaching and academic programmes, staffing levels, University's financial resources, infrastructural facilities, university's partnerships, global trends and policy framework.

Several researchers (Gupta et al, 2013; Per et al, 2014) discuss that the institution's size, growth and expansion can be determined by both internal and external factors. The internal factors depend on motivation, manage ment and the strategic goals of an institution management and the management willingness to grow and innovative. Per et al and Zhou and Gerrit de Wit (2006), further argue that there is compelling evidence that the owner- management's communicated vision and goals have direct effect on the firm's growth. Innovation, communicated vision and goals also have a direct effect on institutional autonomy. On the other hand, Per et al argue that the firm's growth is to a certain extent externally determined, especially by the environment in which a university is located. When the environment offers negative opportunities, the university is likely to stagnate or fail and the reverse is true.

According to Winchester (2005), the changing nature of academic work has resulted in a number of related trends through which productivity of academic work has increased. As staff deal with increasing number of students, staff ratios have risen. There is an intensification of work not only related to teaching loads but also research expectations, reporting and accountability require ments. Borrowing the example of Kenya, Gudo et al (2011) state that the demand for university education has significantly increased and continues to swell, many secondary school graduates and the working class who had not attained "A" level education have used the opportunity of increased access and through openings like adult education, having evening class studies have managed to attain this education and finally qualified to pursue university education. Muhwezi-Murari (2012) submits that since the number of high school students qualifying to jo in the university education supersedes the physical structures, universities have introduced e-learn ing. This arrangement has greatly led to a rapid rate of growth and expansion of universities' size all over the world. Besides that there are also many working people interested in taking on university education to improve their career develop ment. Under such conditions, universities have used Information Technology (ICT) facilities to deliver distance education programmes on-line. Kyambogo University has fallen suit by providing education beyond its main campus in Kampala through its affiliated institutions and distance education learning programmes (Kyambogo University Strategic Plan, 2013). However, the University and Other Tertiary Institutions Act, 2001 as amended in 2006 requires universities whether private or public to "set and co-ordinate national standards for admission of students to the different institutions of Higher Education." The Act therefore infringes on the nature of institutional autonomy of universities that they would have in deciding on who should be taught. This is a form of interference in the internal management of the universities' affairs. The students' enrolment has increased both at Kyambogo University campus and its affiliates as a result of additional programmes as well as the increased number of students qualifying for university education (Kyambogo University Prospectus, 2014). The growth of the university is evidenced by the steady growth in students' enrolment at Kyambogo University campus from 6,500 in 2003/2004 to 22,613 in 2012/2013; in addition, about 29,000 students have been registered for various programmes through the affiliated institutions (Kyambogo University Strategic Plan, 2013).

Since its formation in 2003 as a public university, Kyambogo University has established itself as one of the leading universities in Uganda offering a number of academic programmes suiting market demands and development needs of the country. Kyambogo University currently offers over 121 academic programmes in vocational education, teacher training, hands-on engineering, special needs training, social sciences, pure and applied sciences, entrepreneurship and management (Kyambogo University Strategic Plan, 2013). The university also provides education beyond the campus in Kampala through its affiliated institutions and distance education. Although universities should enjoy institutional autonomy in deciding on what to teach, i.e. curriculum and syllabi, their autonomy is also curtailed by the regulations of the NCHE which require that all universities whether private or public, should have their under-graduate and higher degree programmes accredited. There is a problem in trying to balance university autonomy and NCHE regulations and some institutions tend to resist the decisions of the council because they consider themselves autonomous, for example, IGG's Report (2015) established that Kyambogo University taught programmes that had not been accredited by National Council for Higher Education.

Desroches \& Kirshsten (2014 and Dobson (2010) argue that institutions have continued to hire fulltime staff in faculties but at a slow pace with many of the faculties using part-time teaching staff to provide additional capacity both in teaching and research activities of the university. Kyambogo University Human Resource Performance Report (2014) stipulates that over 60\% of university's teaching staff comprised of the part -time and staff on contractual terms. Kyambogo University's autonomy in the selection of the teaching staff has been guided by the 
increased numbers of newly approved programmes by Senate and accredited by National Council for Higher Education (NCHE Report 2014).

Taiwo (2011) observes that, "The degree of financial autonomy is essential for the effective operation of the universities". As universities get grants from governments to finance university activities, they have to account for the grants and through institutional accountability stitutional autonomy may be compromised because government finance officers who may not be knowledgeable make educational decisions that may have long term adverse effects on institutions. Like elsewhere in Africa, Uganda government uses financial control to influence and direct public universities' rate of growth in terms of capital development and students' intake, staffing, and remuneration payable to the academic staff. Varghese \& Martin (2013) observe that the move to institutional autonomy is negatively affected by financial uncertainties experienced in developing countries. With the receipt of the conditional grants and donations, public universities like Kyambogo are expected to comply with the set terms and conditions, and this affects the decisions concerning tuition fees, students' admission, academic programmes, and staffing levels.

The current infrastructure and facilities at Kyambogo University were designed for a much smaller population and this can be evidenced in the Feasibility Report for the Master Plan for Physical In frastructure which shows that very few buildings are in good physical condition and majority of the facilities need immediate attention. In addition, there are incomplete structures that have been neglected for some time leading to a high level of depreciation (Kyambogo University Strategic Plan, 2013). Inadequate infrastructure and facilities have constrained the growth of the university, affected the quality of academic programmes and research capabilities. Successful implementation of the projects supported by African Development Bank (AFDB) and creation of infrastructure as envisaged in the Master Plan for Physical Infrastructure are of critical importance to the growth and expansion of Kyambogo University.

According to Poyago- Theotoky\& Beath (2002), the university's relationship with other institutions generates benefits to the university such as acquisition of knowledge that can ultimately generate additional profit, skill and knowledge enhancement of its own scientific workforce. Kyambogo University has realized benefits accruing to the university terms of income in form of donations both financial and in-kind contributions in form of human resource in the field of engineering and science to enhance teaching and imparting of skills (Kyambogo University Strategic Plan, 2013).

Universities do not operate in a vacuum but rather in an environment that infringes on their autonomy. Universities are therefore affected by external factors existing beyond their surrounding environment. Universities have grown due to global trends. Brennan et al (2004) and Varghese (2006) contend that "Universities and university systems may be influenced more by what is happening in the wider society - and increasingly in the wider world." Globalization in this regard provides a wider context which challenges institutional autonomy. Muhwezi-Murari (2012) again argues that as donors get involved in the policy formulation and funding of public universities, universities get challenged by the donors to adjust their goals to meet the demands of globalization which results in paradigm shift in outlook. This implies that universities are not autonomous of the external control of d onors and the states in regard to size, growth and expansion. For instance, the Government of Sweden offered assistance to four public universities in Uganda and Kyambogo inclusive to build research capacities (Erik Kruse, 2014). However, this does not mean that there are no conditions attached to the grant thus challenging the university autonomy.

Educational polices affect the institutional autonomy of universities, for instance, Synder (2002) and Keiko (2008) observe that universities in Europe and especially those that were in former East bloc countries have weaker trad ition of institutional autonomy. This is because they were traditionally controlled by ministries of education, exercising strong, centralised authority. Kilonzo (2011) argues that the Kenyan Government in 2010 through the Ministry of Higher Education (MOHE), the then minister announced the need to revise the policies of govern ment funding in public Higher Institutions of Learning in which he disregarded the funding of social sciences students, emphasizing that those aspiring to take up sociology and anthropology in the universities would have to fully incur the cost of training without support from the government, and students qualify ing for courses relevant to growth of the economy like medicine, engineering, architecture, actuarial sciences and other scientific related courses would receive full financial support from government. The Ugandan government has a similar policy of sponsoring students pursuing science related programmes of Kyambogo University (The Government White Paper on Education, 1992).

\section{Theoretical Foundations}

The systems theory by Ludwig von Bertalaffy (1940, op cite Heylighen et al, 1992), is apt to the study. Von Bertalanffy emphasized that systems are open to, and interact with the environ ment, and that they acquire qualitative by new proportions through emergence, resulting in continual evolution. Rather than reducing entities (e.g. human body) to the properties of its part or elements (e.g. organs or cells), systems theory focuses on arrangement of and 
relation between the parts which connect to the whole system. The particular organization determines a system, which is independent of the concrete substance of the elements (e.g. particles, cells, transistors, and people). In education, the system theory is applied in terms of the relationship among its components (teachers, students, content and context) and the relationship the system has with its environ ment (Marisa, 2004). As Musaazi (2006) discusses, a system is a set of interacting parts forming a unified whole system. Musaazi views a school as a system with various components interacting, working ideally to achieve the main purpose, goals, and objectives for which the school was established. Therefore, when changes are made in an education system, one or more of the relationships can be affected. By implication, an external interference on part of an education institution affects the autonomy of the entire system.

\section{Methodol ogy}

The paper adopted a qualitative research design that entirely employed a review of documents both published and unpublished regarding institutional autonomy with reference to size, growth and expansion and Kyambogo University in particular. The documents reviewed consisted of Kyambogo University Strategic Plan, prospectus, journals, reports, articles, conference papers and other policy documents concerning the students' enrolment, staffing levels, academic programmes, infrastructural facilities, financial resources, policy frameworks, university's partnerships and global trends. The authors conducted interviews with members of staff (academic and administrative) on Kyambogo University's autonomy with regard to size, growth and expansion. The qualitative method was adopted because of its strength in offering contextual in- depth understanding of institutional autonomy. The members of staff interviewed were purposively selected because they experience the dynamics of institutional autonomy.

\section{Findings}

The study findings revealed that Kyambogo University heavily relied on funds raised from private students thus making the institution to be in a limping position, a financial position that was unsustainable in the long run and would lead to the closure of the university due to a heavy debt burden, in accordance with the performance report (Kyambogo University Strategic plan, 2013). It was also established that the university was facing inadequate funding which affected Capital Development of Infrastructure describing them as crumbling, with need to replace asbestos roofing which are hazardous to users, very old and overwhelmed sanitary facilities, and the non -functional sewage system. Kyambogo University Admissions Board makes most of the decisions concerning the admission of students on behalf of Senate Committee in accordance with the set minimum admission requirements of National Council for Higher Education. In addition, the Programmes Committee on behalf of Senate and guided by National Council for Higher Education Framework (2014), makes decisions concerning the content and teaching load of all university programmes.

\section{Discussion}

Different views are held on the institutional autonomy that universities want to enjoy. For instance, in the study conducted by Bailey (2014), a strong view dismissed institutional autonomy as a prolonged past escapism where the university was an ivory tower where government would have no business with the university. The findings asserted that universities are expected to be answerable to the public for what they do an idea which dismisses the prolonged academic freedom and escaping public cross- examination. This would make universities to be responsive to society needs and accountable to the public (Synder 2002) as already observed. However, basing on the study findings, a level of autonomy is necessary in some field.

In this study, it has been established that Kyambogo University has undergone a lot of changes which have led to its growth in size and expansion. Kyambogo University is unique in reference to its inception as a merger of the three formerly distinct institutions with different areas of specialty; Uganda Polytechnic Kyambogo (UPK) for technical training, Institute of Teacher Education Kyambogo (ITEK) for teacher training and Uganda National Institute of Special Needs Education (UNISE) for special needs education. These institutions possessed their respective affiliated institutions which ended up becoming part of Kyambogo University by law (Universities and Other Tertiary Institutions Act 2001 as amended).

Kyambogo University students' enrolment has increased both at campus and its affiliates as a result of additional programmes as well the increased number of students qualifying for university education (Kyambogo University Prospectus, 2014; Kyambogo University Affiliation Policy, 2012). The growth of the university is evidenced by the steady growth in students' enrolment at campus from 6,500 in 2003/2004 to 22,613 in 2012/2013; in addition, about 29,000 students have been registered through the affiliated institutions (Kyambogo University Strategic Plan, 2013). This was confirmed by the Acting Deputy Registrar in charge of Extensions and Affiliated Institutions Division, Academic Registrar's Department, who said that "the affiliation of Early Childhood Development Teacher Training 
Institutions to Kyambogo University did not only increase the number of students, but also led to the university's growth and expansion in the area of operation". Kyambogo University exercises its autonomy in the selection of students for admission to various academic programmes through different admission entries; Certificate and Diploma Entry Scheme and Direct Entry Scheme for the undergraduate programmes and the Post graduate Scheme for the postgraduate programmes. However, Government established bodies and policies such as Joint Admissions Board (JAB), District Quota System, Gender Affirmative Action, and policies on admission of special needs and sports students. This was also noted by Taiwo (2012) and it interferes with university autonomy in processing entrance and admission to public universities, Kyambogo University inclusive. In several scholarly reports (Kasozi, 2006; Katunguka, 2013), it has been observed that there has been increased demand for university education and thus becoming one of the major determinants of the increase in size, growth and expansion of Universities. Despite constrained resources and facilities (Kasozi, 2006; IGG Report, 2014). Besides, there has been increase in the number of "A" level secondary school graduates who have gone through the secondary cycle and have obtained the minimum entry requirements for joining Universities.

As already noted, in an endeavor to exercise institutional autonomy, Kyambogo University offers over 121 academic programmes in different areas of specialty; vocational education, teacher training, hands -on engineering, special needs training, social sciences, pure and applied sciences, entrepreneurship and management which suit market demands and development needs of the country (Kyambogo University Strategic Plan, 2013). The university also provides education beyond the campus in Kampala through its affiliates and distance education learning programmes. However, the university's autonomy to expand the size of the programmes offered to her clients is limited by decisions of the NCHE with its power and authority to accredit progra mmes offered by all higher education institutions whether operating as public or private entities in Uganda. The IGG's Report (2015) refered to it as "irregular" when Kyambogo university either by commission or by omission offered unaccredited programmes. Therefore, university autonomy is not absolute due to instituted regulatory bodies that infringe on it.

Institutions have continued to hire full-time staff in faculties but at a slow pace, with many of the faculties using part-time teaching staff to provide additional capacity in teaching and research activities of the university (Desroches \& Kirshsten 2014; Dobson, 2010). This was echoed in the statement of the Acting Director, Human Resources, Kyambogo University, that "nearly $30 \%$ of the established positions are vacant and the percentage of part-time academic staff is more than 60\%" and further that "the proportion of $\mathrm{PhD}$ holders to the total number of academic staff at the university is far below the ideal NCHE standards (60\% of staff)". This resonated with the IGGs Report (2015) and NCHE (2014) that staffing levels were inadequate, forcing the university to rely more on part-time academic staff in both teaching and research activities. Therefore, the institutional right to select who to teach is dimin ished. Nevertheless, the University staffing levels are heavily affected by govern ment decisions on recruitment of staff because the university has to seek permission from Ministry of Public Service to recru it staff in liaison with the Ministry of Education and Sports with the approval of Ministry of Finance. The National Council for Higher Education (NCHE) Act, 2001, empowers the Min ister of Education and Sports to "is sue directives of a policy nature to all institutions of higher education, whether public or private, and the institutions shall effect those directives." Such directives affect the university autonomy in determining the size of staff, its growth and expansion. This challenges institutional autonomy since educational policies enacted by political leaders affect the operations of the universities.

The university's partnership with the international agencies as well as overseas universities and other institutions confirms the university's autonomy in determining its size, growth and expansion. Kyambogo University has established partnerships with reputable institutions like Oslo and Arkershus University College in Norway, Kenyatta University, George Town University, University Winneba, Mombasa Polytechnic University College, (Kyambogo University Strategic Plan, 2013). Sharing the beliefs of scholars like Poyago-Theotoky \& Beath (2002), Kyambogo University Public Relations Officer intimated that the university has benefitted through the "acquisition of knowledge and skills, and donations extended to the university both financial and in-kind contributions such as equipment and expertise in form of human resource in the field of engineering and vocational pedagogy". However, these benefits from partners have shortcomings too. For instance, there is a tendency for universities to lose their autonomy in making decisions on what research projects to undertake and normally carry out donor led projects where the donor has interests (Bailey et al 2011; Bisaso 2013; Kawalya, 2012). This infringes on the institutional autonomy.

Highly centralized policy making on higher education restricts the autonomy of universities and politicises them, thus subjecting the learning experience to political objectives. Policy centralization makes it difficult for universities to be responsive to changes in knowledge, the labour market and economic development. Every higher education institution must have appropriate and effective internal structures and mechanisms for monitoring its institution 
quality control procedures to ensure quality (National Council for Higher Education, 2014). The academic policies such as Kyambogo University Quality Assurance Policy (2014) stipulates the university's authority and freedom to regulate the standard and quality of education at the university and its affiliates, emphasising the role of the university with regard to teaching, research and community engagement. The university is in the process of establishing a Directorate of Quality Assurance in accordance with the Universities and Other Tertiary Institutions Act of 2001 as amended as well as the approved Kyambogo University Establishment (2006).

\section{Conclusion}

From the foregoing, it is clear that there has been enormous realization of increase in size, growth and expansion of higher education institutions of learning, universities inclusive, across Uganda. This has been attributed to both internal factors and the university's response to external environment. The institutional autonomy with reference to universities in determining their size, growth and expansion rotates around the students' enrolment, number of academic programmes, staffing levels, infrastructure and instructional facilities, financial resources, university's partnerships, policy frameworks and response to global trends.

Kyambogo University which emerged as a result of a merger of three different institutions, namely: UPK, ITEK and UNISE in 2003, by an Act of Parliament, had a direct component of increasing student enrolment as well as expansion of the institution. Besides, Kyambogo University has also got a number of affiliated institutions which include Primary Teachers' Colleges, National Teachers Colleges, Technical Institutions and Early Childhood Develop ment Teachers Institutions. It also conducts e-learning and distance education especially to those offering the Dip loma in Primary Education. All these have greatly contributed to the increase in size and its rate of growth and expansion of the university as it was anticipated in its strategic plan 2012/2013 to 2017/2018.

Kyambogo University by nature just as like any university is supposed to enjoy autonomy in managing its internal affairs including admission of students, taking full charge of the academic programmes, decisions on who to teach and what to teach, how to mobilize and utilize resources. It is therefore imperative that Kyambogo University develops internal capacities to properly perform such functions. In this regard, the university can guarantee its autonomy. However, we have noted in this article that Kyambogo University has not been able to perform these functions autonomously due to external forces and limitations.

It has been established that government and its agencies have to undertake an overseer's role which ends up interfering with the operations of public institutions like Kyambogo University. For example, NCHE, directly over sees academic programmes offered by the universities through accreditation of such programmes and setting minimum standards accordingly. However the overseer's role of government cannot be totally negative because it regulates Kyambogo University in properly keeping to the required standards.

\section{Recommendations}

Although universities need to enjoy their autonomy, they find it difficult since they operate in an open system. This is because the inputs of the university who are the students for example are drawn from the environ ment outside the university and they are also prepared to serve and operate in the environ ment both within and outside the university. The university should therefore be mindful of this fact when considering its size, rate of growth and expansion. While Kyambogo University should obtain a level of autonomy in some areas, it is recommended that government should continue to monitor and supervise and regulate the operations (mainly supervisory role) of the universities to cater for the interests of the public. In addition, there are could as well be some inherent problems in such institutions that require direct government intervention. In order for Kyambogo University to enjoy a high degree of autonomy, the university management should look for a way of moving away from the traditional methods of generating income which include over reliance on government grants (first stream) and tuition (Second stream), to emphasizing the third stream that encompasses alumni contributions, donations and fund raising and other entrepreneurial options.

\section{References}

Altbach, P.G., Reisberg, \& Rumbtey, L.E (2009). Trends in global higher education, Tracking an academic revolution. A report prepared for the UNESCO 2009 World Conference on Higher Education.

Asian Development Bank. (2012). Counting the cost: Financing Asian higher education for inclusive growth, Mandaluyong City.

Bailey, T. (2014). The role and function of Higher Education Councils and Commissions in Africa: A case of Uganda National Council for Higher Education, CHET HERANA, South Africa. Retrieved from www.Compresssdsi.com

Bisaso, R. (2013). Academic capitalism in responsiveness of science academic units Makarere University. Comperative and International Higher Education 5(2013). 
Bloom, D., Canning, D., \& Chan. (2006). Higher education and economic development in Africa. Human Development Sector African Region.

Chowdry, H., Crowford, C., \& Dearden, L. (2010). Widen participating in higher education: Analysis using linked administrative data. Institute for Fiscal Studies.

Desrochers, D. M., \&Kirshstern, R. (2014). Labor Intensive or Labor Expensive? Changing Staff and Compensation Patterns in Higher Education, Delta Coast Project, American Institutes for Research.

Dobson, I. (2010). Uneven Development: The Disjointed Growth of University Staffing Since Dawkins . People and Place, 18(1).

Government of Uganda. (1992). The White Paper on Education.

Gudo, C. O., Ole1, M. A., \& Oanda, O. (2011, November). University expansion in Kenya and issues of quality education; Challenges and opportunities. International Journal ofBusiness and Social Sciences, 2(20).

Gudo, C.O. et al. (2011) University Expansion in Kenya and Issues of Quality Education: Challenges and Opportunities.

Katunguka, S. (2011, October). The role of higher education in poverty eradication in Uganda: The experience of Makerere University through innovations at Makerere Committee. Uganda Higher Education, 2(2).

Kawalya, J. (2012). The repositioning of Makerere University structure: Its effect on College of Education and external studies library services, presented to SCECSA L XXth Conference hosted by KLA on 4-8 ${ }^{\text {th }}$ JUNE 2012 Venue. LAICO Regency Hotel Nairobi, Kenya.

Keiko, Y. (2008). Neo-liberalism and change of higher education policy: England and Japan. Policy Futures in Education, 6(2). Retrieved from www.wwordsco.Uk/PFIE

Kyambogo University. (2013). Strategic Plan.

Kyambogo University. (2014). Prospectus.

Kyambogo University. (2014). Quality Assurance Policy.

Muhwezi-Murali, M. A. (2012). A paper presented on higher education in Uganda.

National Council for Higher Education Act.(2001).

O'Neill, J. (2013). Creative Research Ethics in the Enterprise University; what price academic freedom?. Policy Features in Education, 11(6). Retrieved from www.wwords.co.uk//PIFE

Okwach Abagi, et al. (2005). New Trends in Higher education; Private Higher education in Kenya, International Institute of Educational Planning- IIEP - UNESCO.

Poyago- Theotoky, J., Beath, J., \& Siegel, D. S. (2002). Universities and Fundamental Research: Reflection on the Growth of University Partnerships, Oxford Review of Economics Policy.

Rono, J. K. (2002). Structural Adjustment Programmes in Kenya. Journal of Social Development in Africa.

Snyder \& Dillow. (2012). The economics of higher education: The department of the treasury with the department of education.

Taiwo, E.A. (2011). Regulatory bodies, academic freedom and institutional autonomy in Africa: Issues and challenges - The Nigeria example; Council for the Development of Social Research in Africa 2012. Journal of Higher Education in Africa, 1(1\&2).

The Inspectorate of Government. (2015). Report on Investigations into Mismanagement and Corruption at Kyambogo University.

Universities and Other Tertiary Institutions Act 2001 as amended.

University of Aberdeen. (2015). Academic Quality Hand Book, Section 2 Quality Assurance in Higher Education.

Varghese, N. V. (2006). Growth and expansion of private higher education in A frica, International Institute for Education for planning. Retrieved from http://www.unesco.org/iiep

Winchester, H. P. M. (2005). Staffing Issues for Universities. Paper Presented At University of South Africa $3^{\text {rd }}$ Annual Higher Education Summit, Melbourne.

World Bank. (1991). Kenya Universities Investment Project, Staff Appraisal Report, Washington, DC, the World Bank. 